\author{
A REVIEW OF POTENTIAL \\ TURBINE TECHNOLOGY OPTIONS \\ FOR IMPROVING THE OFF-DESIGN \\ PERFORMANCE OF DIRECT COAL - FIRED \\ GAS TURBINES IN BASE LOAD SERVICE.
}

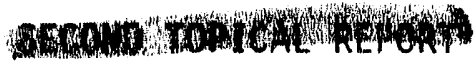

By: Richard L. Thomas

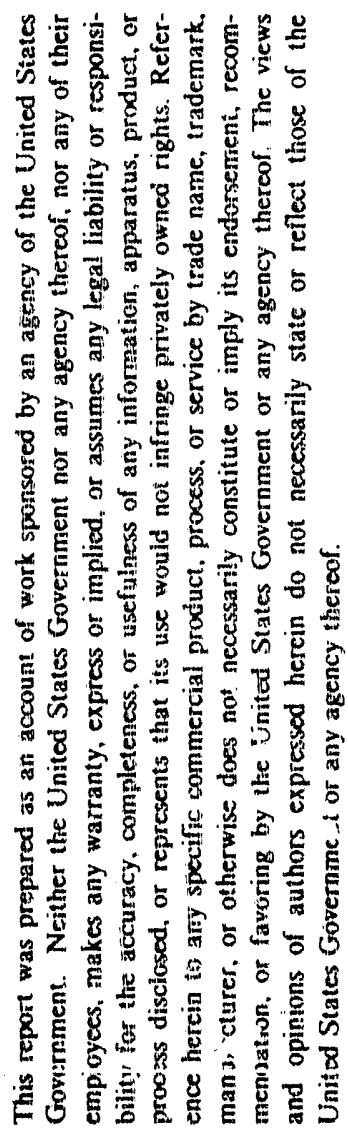
Work performed for the U. S. Department of Energy Morgantown Energy Technology Center
Under Contract No. DE-AC21-85Mgrapde

$$
\text { by }
$$

KOH Systems, Inc.

Rockvilie, Maryland
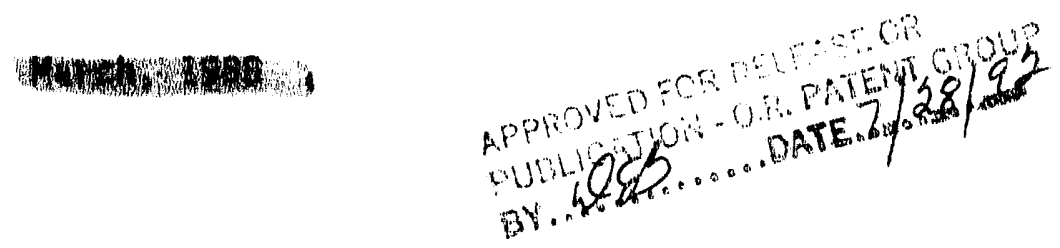

DISTRIBUTION OF THIS DOCUMENT IS UNLUMITEO

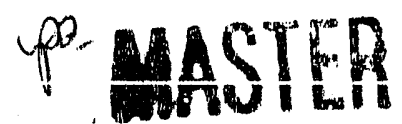




\section{"A REVIEW OF POTENTIAL TURBINE TECHNOLOGY OPTIONS FOR IMPROVING THE OFF-DESIGN PERFORMANCE OF DIRECT COAL-FIRED GAS TURBINES IN BASE LOAD SERVICE"}

CHAPTER

ACKNOWLEDGEMENTS

1.0 INTRODUCTION

2.0 SUMMARY

3.0 TECHNOLOGY OPTIONS FOR IMPROVING EROSION PERFORMANCE

3.1 Basic Hydraulic Design Considerations

3.2 Current Turbine Erosion Research

3.3 Potential Technology Options

4.0 DPTIONS FOR IMPROVING SIMPLE CYCLE THERMODYNAMIC 11 PERFORMANCE.

4.1 Experience with Alternative Gas Turbine Cycle Designs 11

4.2 Potential Options with Commercial Machines

4.3 Novel Cycle Designs

4.4 Summary

5.0 A GAS TURBINE DESIGN PERSPECTIVE ON HIGH TEMPERATURE 21 MATERIALS TECHNOLOGY

6.0 POTENTIAL. RESEARCH OPTIONS TO BE EVALUATED 25

REFERENCES

\section{LIST OF TABLES AND FIGURES}

TABLE 3.1 Sample Calculation for a Preliminary Turbine Stage Design

TABLE 4.1 Pre-1960 Experience with Open-Cycle Configurations to Improve Gas Turbine Efficiency and Output

TABLE 4.2 Comparison of Performance Characteristics for Recuperator and/or Intercooling Modifications to a Given Gas Turbine Design

TABLE 4.3 Performance Comparison of Reheat Cycles at Various Comprission Ratios

TABLE 4.4 Effect of Cycle Pressure Ratio on Regenerative Gas Turbine Design at a Turbine Inlet Teinperature of $1400^{\circ} \mathrm{F}$

TABLE 6.1 Matrix of Potential Research Options for 


\section{ACKNOWLEDGEMENTS}

Mr. Nelson F. Rekos of the METC Heat Engines Branch is the technical project officer for this study. His helpful comments on earlier versions of this report, and his input and guidance during the study are appreciated.

A special note of appreciation is extended to the following individuals who were contacted by telephone for opinions on technology approaches for solving the problem of aijal flow turbine operation in particle laden gas streams.

- Mr. Richard Foster-Pegg, Chairman

- Mr. Kymus Ginwalla, President

- Dr. Charles Jahnig

- Mr. Bruce Nicol, Vice President Engineering

- Dr. G. E. Provenzale, Member

- Professor Widen Tabakoff

- Professor David Wilson

- Professor Tah-Teh Yang
SME/IGTI* Technical Committee on loal Utilization

Northern Research and Engineering Corp. Woburn, Massachusetts

Consulting Chemical Engineer

Rumson, New Jersey

Dresser-Rand, Inc.

Corning, New York

ASME/IGTI* Technical Committee on Turbo Machinery

Department of Aerospace Engineering University of Cincinnati

Department of Mechanical Engineering MIT

Department of Mechanical Engineering Clemson University

* ASME International Gas Turbine Institute, Atlanta, Georgia

The contributions from these individuals greatly assisted the author in formulating the general approach and conclusions presented in the report.

The author's interpretation of the consensus resulting from these telephone contacts is believed to be correct. However, possibilities remain that subjective judgement may have misconstrued portions of conversations or that nuances in conversations were not detected. In addition, the individuals were not given the opportunity to review the report. Accordingly, the appearance of an individual's name on the 7 ist should not be considered a direct or implied endorsement by that individual of anything in this report. 


\subsection{INTRODUCTION}

The January, 1988 draft topical report, entitled "An Assessment of off. Design Particle Control Performance on Direct Coal-Fired Gas Turbine Systems" [Ref. 1.1], identified the need to assess potential trade-offs in turbine aerodynamic and thermodynamic design which may offer improvements in the performance, operational and maintenance characteristics of open-cycle, direct coal-fired, combustion gas turbines.

In this second of a series of three topical reports, an assessment of the technical options posed by the above trade-offs is presented. The assessment is based on the current status of gas turbine technology. Several industry and university experts were contacted to contribute to the study. Literature sources and theoretical considerations are used only to provide additional background and insight to the technology involved.

The various technology options reviewed could be attractive to offset performance debits which may accrue from adjustments to machine operation to avoid erosion and fouling problems. Accordingly, the report focuses on technical options which present research alternatives to increase impact tolerance (resistance to erosion) of power turbine blading and/or improve gas turbine cycle performance at reduced turbine inlet temperature.

The intent of presenting the research alternatives is to identify potential paths that could be pursued in one or more applied research programs. At this point, only a listing of turbire technology research concepts which may be applicable to advancing direct coal-fired gas turbine research is presented. An assessment of these research alternatives as well as recommendations for future research will be the subject of a third and final topical report. 


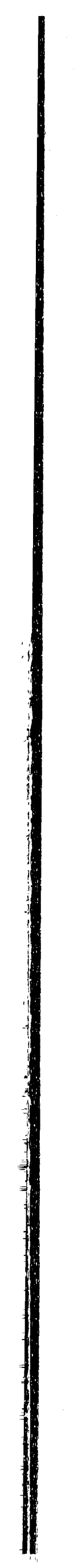




\subsection{SUMMARY}

The results of this study point to a matrix of technical options in gas turbine erosion, thermodynamic and material design which could be pursued in an applied research program to achieve improvements in direct coal-fired turbine performance. Such improvements may be necessary to overcome turbine erosion and fouling effects that could accrue from operation in a particle-laden gas stream with characteristics differing from that established by particle control system design criteria. Additionally, technical refinements in the above design areas could play a key role in enhancing the economical attractiveness of gas turbines utilizing coal fuels in base load applications.

From an erosion standpoint, there appears to be no technical barrier to developing turbines capable of accommodating particle sizes and loadings much greater than present gas turbine limits. The technology involved centers on optimization of the turbine blade profile versus economic trade-offs in turbine efficiency and turbine blading life cycle costs. Existing design models for predicting turbine erosion rates and patterns can be used to evaluate modifications which would improve the erosion tolerance of specific turbine designs similar to those of interest to the present DOE program. However, to extend this technology to a new class of erosion resistant turbine designs, bench-scale research is needed to establish particle/material erosivity correlations for the properties of direct coal-fired turbine gas streams.

Similar conclusions can be drawn in the area of thermocycle design. Eight alternative cycle configurations were identified with efficiency and/or specific power output advantages over existing simple-cycle turbine designs. These advantages could be used to offset performance debits introduced by potential reduction in cycle temperature to control turbine fouling.

In terms of increasing difficulty of development, these cycles range from modifications to existing turbines using proven compressor intercooling and/or turbine exhaust heat recuperator technology - to the development of an advanced cycle using reheat at compression ratios above $10: 1$. Of particular interest is the performance and development advantages of a low-pressure ratio (4:1), regenerative cycle design. The development of such a cycle could be based on commercially available, expansion turbine designs with proven operating experience in erosive gas streams.

Finally, a review of high-temperature materials technology applicable to turbine design highlights the potential importance of ceramic materials for direct coal-fired turbine development. The use of zirconium oxide overlay coatings over existing metallic turbine blade coatings may be necassary to achieve the erosion/corrosion resistance required for coal combustion gas streams. The technology for applying such coating systems exists and should be included in the various turbine material evaluation programs now in progress. Additionally, existing ceramic recuperator technology may offer designs which could enhance regenerative cycle performance. 
A matrix of possible research alternatives that could be used to capture the technology options identified in this study is presented in Chapter 6.0. The research alternatives and technical options shown were developed through telephone contacts with individuals currently in gas turbine design and research outside the present DOE Program. Those contacted are Tisted on the Acknowledgements page of this report. All individuals contacted underscored the value of applied research studies directed at anaiyzing specific turbines and designs.

The general consensus resulting from these contacts is that gas turbine erosion performance can be greatly improved and that turbine inlet temperatures will most likely need to be adjusted to avoid turbine fouling problems. cycle modifications represent a practical means to overcome performance penalties should reductions in turbine inlet temperature be required.

An analysis of the ramifications of the various technology options presented in this study on the present DOE Program as weil as incentives for research will be the subject of the next and final topical report. 


\subsection{TECHNOLOGY OPTIONS FOR IMPROVING TURBINE EROSION TOLERANCE}

Normally, turbine erosion is not considered as a design parameter in commercial, industrial gas turbine designs; the implicit assumption is made that gases entering the turbine are not erosive. Design considerations center on the stress rupture life of turbine blading and optimizing hydraulic efficiencies to achieve economic component replacement intervals and overall engine heat rates consistent with those required for baseload service. The maximum erosion tolerance of such designs has been fairly well established from operating experience to be on the order of $100 \mathrm{ppm}$ of particulates (maximum particle size of 10 microns) in the gas stream entering the turbine.

The design principles for extending the erosion tolerance of commercial turbine designs to accommodate increased particle loadings are generally understood. Additional insight to this understanding is being provided by current gas turbine erosion research. This research promises more erosiontolerant designs by the use of three dimensional modeling of particle flow through the turbine gas passages. In addition, correlations of high-temperature erosivity with particle physical and chemical properties are being developed for commonly used gas turbine materials.

An evaluation of basic turbine hydraulic design considerations in relation to this ongoing erosion research is presented as a basis for defining potential options for improving the erosion tolerance of direct coal-fired turbines.

\subsection{Basic Hydraulic Design Considerations}

The use of material thicknesses above that required for structural integrity is a widely practiced design option for increasing the service life and operating tolerance of process equipment exposed to erosive gas streams. However, use of such a material erosion allowance in turioine design involves trade-offs in hydraulic performance. These trade-offs largely govern the practical erosion allowance thickness that can be used.

From an erosion standpoint, the main factors governing erosion rate for a given turbine material and particulate stream are particle velocity and impact angle relative to the material surface. These factors in turn are quantified in turbine design by the nozzle gas velocity and the blade turning angle of the gas to achieve the required energy transfer to the turbine shaft.

The efficiency of this energy transfer and overall impact on turbine design may be evaluated by the following design parameters:

- The gas isentropic expansion energy (heat drop) available for turbine work (as determined by the turbine inlet temperature and pressure ratio);

o The blade tip speed (as determined by allowable stress considerations);

- the pressure drop taken across the turbine rotating blades (as determined by the type of stage design, i.e., impulse, reaction, etc.). 
To illustrate the design interdependency of the above parameters and the impact of erosion allowance on efficiency, two examples are discussed in the following paragraphs. In the first example, the parameters are used to establish a preliminary design for a commercial turbine optimized for efficiency without an erosion allowance. The second example presents the results of a design study to define conceptual modifications which could extend the erosion life of an existing commercial turbine by about 50 percent.

As a starting point, basic turbine design theory has established that the optimum stage efficiency and the required number of expansion stages is a function of the ratio of the blade tip speed to the nozzle gas velocity (u/c) [Reference 3.1]. For impulse turbines, where the stage heat (enthalpy) drop is taken across the nozzles, optimum efficiency occurs at a $u / c$ value of 0.48 . The corresponding value for a reaction stage is 0.85 . Reaction turbines have a higher efficiency because the stage heat drop is taken across both the nozzle and b? ades.

The above $u / c$ values are closely approximated in commercial turbine designs. Efficiencies above 90 percent are achieved by special attention to: 1) biade geometries to minimize entrance and exit losses (twisted blades); 2) the number and thickness of blades to reduce losses due to deviations between gas velocity and blade profiles (slip); and 3) leakage/pressure losses between stages. Impulse staging can be used to advantage in commercial designs to reduce the number of stages and/or lower gas temperatures to the first stage blades.

Table 3.1 presents a sample calculation for a preliminary reaction turbine design using the above design parameters. A range of stage heat drops for both impulse and reaction designs at various blade tip speeds is shown. Also the gas isentropic heat drops at an expansion efficiency of 88 percent is shown for a range of turbine inlet temperatures and pressure ratios. For a turbine inlet temperature of $1800^{\circ} \mathrm{F}$ and pressure ratio of $10: 1$, a three stage reaction turbine with a blade tip speed of 1200 feet per second is indicated to be a satisfactory design.

Identical cross sections for the rozzles and blading are selected for a 50 percent reaction design where the stage heat drop is taken equally across the nozzle and the blading. To maximize work output, the nozzle and blade exit angles should be made as small as possible as indicated in the stage gas velocity diagram. This practice favors making the trailing edges of the blading as thin as possible which is undesirable from an erosion standpoint.

For the angles shown, a three-stage turbine would generate about 11,800 horsepower with a gas flow of 40 pounds per second. This would correspond to a net output rating of about 4500 horsepower after subtracting the power requirements of the air compressor. These design parameters closely approximate those of direct coal-fired turbines being utilized in the present proof-of-concept test program. 
TABLE 3.1

SAMPLE CALCULATION FOR A PRELIMINARY TURBINE STAGE DESIGN

- CALCULATION OF STAGE HEAT DROP $(\Delta h)$ AS FUNCTION OF RATIO OF ROTATING BLADE TIP SPEED (u) TO NOZZLE GAS VELOCITY (C)

$$
e=u / c \quad \& \quad h=c^{2} / 50,000 \text { (for } 100 \% \text { nozzle efficiency, i.e. } v=(2 \mathrm{gh})^{1 / 2}
$$

IMPULSE STAGE, $e=0.48$

\begin{tabular}{lrrr}
\hline u, fps & 800 & \multicolumn{1}{c}{1000} & 1200 \\
c, fps & 1666.7 & 2083.3 & 2500 \\
Ah, Btu/\# & 55.6 & 86.8 & 125
\end{tabular}

REACTION STAGE, $e=0.85$

$\begin{array}{lll}800 & 1000 & 1200 \\ 941.2 & 1176.5 & 1411.8 \\ 35.4^{\star} & 55.4^{\star} & 79.7^{\star}\end{array}$

*50\% reaction turbine with equal heat drop across nozzle and blading.

- AVAILABLE ISENTROPIC EXPANSION WORK AVAILABLE FOR VARIOUS TURBINE INLET TEMPERATURES (TIT) AND PRESSURE RATIDS $\left(P_{r}\right)$ FOR A TURBINE EFFICIENCY OF 0.88. (Enthalpy from Keenan \& Kaye Air Tables).

\begin{tabular}{|c|c|c|c|c|}
\hline \multirow[b]{2}{*}{$\mathrm{P}_{\mathrm{r}} / \mathrm{TI} \mathrm{T}^{\circ} \mathrm{F}$} & \multicolumn{4}{|c|}{$\Delta h=B t u / \#$ (Exhaust Temperatures, ${ }^{\circ} \mathrm{F}$ ) } \\
\hline & $6: 1$ & 8:1 & $10: 1$ & $12: 1$ \\
\hline $\begin{array}{l}1400 \\
1800 \\
2200\end{array}$ & $\begin{array}{l}161.2(708) \\
197.1(981) \\
235.0(1247)\end{array}$ & $\begin{array}{l}181.0(620) \\
221.2(876) \\
262 .(1134)\end{array}$ & $\begin{array}{l}194.7(596) \\
252.2(799) \\
282.8(1045)\end{array}$ & $\begin{array}{l}205.7(507) \\
252.2(739) \\
299.0(976)\end{array}$ \\
\hline
\end{tabular}

- FOR TURBINE INLET TEMPERATURE OF $1800^{\circ} \mathrm{F}$ AND PRESSURE RATIO OF $10: 1$ WITH TURBINE EFFICIENCY $=88 \%$, SELECT A THREE STAGE REACTION TURBINE DESIGN WITH A TIP SPEED OF $1200 \mathrm{fps:}$
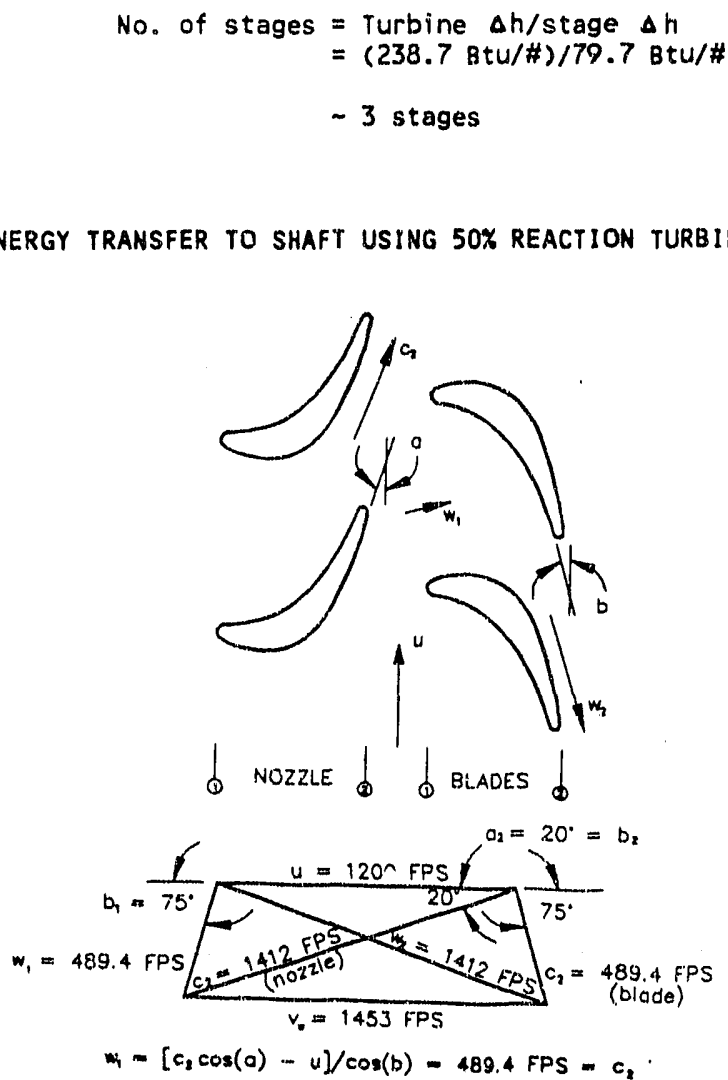

NOTATION:

$c=$ absolute gas velocity

$W=$ gas velocity relative to blade

$a=$ gas jet angle

$b=b l a d e$ inlet and outlet angle

$u=$ blade tip speed

WORK/STAGE:

Tangential force on blade/\# air

$f=(\# / \mathrm{sec} \times 1453 \mathrm{ft} / \mathrm{sec}) / \mathrm{g}$

$f=45.1 \# / \#$ air

$$
\text { OR }
$$

$w k=45.1 \# / \#$ air $\times 1200 \mathrm{ft} / \mathrm{sec}$

$=54,149 \mathrm{ft}$ \#/sec/\# air

or $=98.4 \mathrm{HP} / \#$ air

or $=69.6 \mathrm{Bru} / \#$ air 
'The provision of an erosion allowance for such a blade design would require a general thickening of thi blade. Operating experience has shown that the primary area of erosion is on the concave (pressure) side of the turbine flow passages. The corresponding points for the nczzles and blades are the trailing edge and leading edge, respectively. Design modifications in these areas would alter the blading entrance and exit angles and thus affect turbine output and efficiency. (Refer to diagram in Table 3.1).

In addition, increasing the blade thickness requires that the blade height (length) be increased. This is necessary because the flow area must satisfy flow continuity considerations. Increasing the blade length introduces a design reiteration because the ratio of blade length to wheel diameter is set by the allowable stress for a given tip speed. Design reiteration could result in increasing the gas exit angle from the blade, the blade tip speed, or the number of blades. Directionally, these modificatio'ls all tend to decrease efficiency and increase the number of stages.

An example of a design reiteration for a conceptual modification to a Westinghouse 501 turbine (a reaction-type turbine) may be found in Reference 3.2. In this design study, the objectives were to increase trailing edge thicknesses by about 40 percent and to use less erosion sensitive blade contours in the first two stages. The results are shown below in terms of the erosion-related life of a blade row normalized to the first row stator.

\section{EROSION-RELATED OPERATING LIFE RATIOS}

\section{EXISTING DESIGN CONCEPTUAL MODIFICATION}

1st Stator

1st Rotor

2nd Stator

2nd Rotor

3rd Stator

3rd Rotor

4 th Stator

4th Rotor
1.0

0.16

0.83

0.49

1.50

2.60

0.75

2.60
$1.0 *$

0.26

$1.10^{*}$

$0.16 * *$

0.62

0.23

0.54

0.31

* Stress-1imiced

**Projected 1 ife 18,000 hours

Thus it can be seen that the erosion lives of various components for commercial turbine designs can be adjusted within limits. In this case, additional benefits from the conceptual redesign included lower blade replacement costs due to the reduced number of blades and simple profiles and improved fouling resistance due to the increased flow area of the airfoil sections most sensitive to fouling. The reported efficiency loss for this conceptual modification was estimated to be on the order of 2 percent.

\subsection{Current Turbine Erosion Research}

The subject if turbine erosion research has received renewed attention over the past ten years. Theoretical, bench-scale and applied erosion research have been and are being carried out under sponsorship of various industrial, 
military and other governmental organizations. The work th the University of Cincinnati in the area of three dimensional modeling of perticle flow through turbine flow passages and in the area of high temperature erosivity correlations with commonly used gas turbine materials [Reference 3.3] is typical of such renewed attention.

The results of research in the erosion modeling of multistage turbines appear to indicate that if the particle size and erosivity characteristics are known, the erosion rates and patterns can be predicted with a fair degree of certainty [References 3.4 and 3.5]. Of particular iriterest is the potential ability to predict turbine erosion by particles larger than 10 microns in diameter. This size particle is considered to be the highest tolerable limit for commercial turbine designs based on operating experience.

The erosion of twisted blade profiles (high turning angle) has been evaluated for particle sizes up to 100 microns in diameter [Reference 3.6]. In addition, the erosion of brittle materials (e.g., ceramic blades) has been evaluated for 15 micron particles [Reference 3.5]. The general conclusion from this latter evaluition is that erosion would tend to neak at the leading edge of the blade as opposed to peaking at the trailing edge as in blades fabricated from more ductile materials. From a design standpoint, such information could lead to the economical use of field replaceable sheathing and/or hard facing materials to control erosion in critical areas for particle sizes larger than 10 microns.

of further interest is the research directed at developing particle and turbine materials erosivity correlations for use in modeling the erosion of large particles in turbine flow passages [Reference 3.7 and 3.8 ]. Reference 3.7 reports the effects of varying particle size from 5 to 180 microns on the erosion rate of Inco 78 ! and Rene 41 gas turbine blade materials at a temperature of $900^{\circ} \mathrm{F}$. The reported results show that erosion rates increase up to a particle size of about 40 microns at which point the erosion rate becomes practically constant with increasing particle size. One design inference that could be drawn from this information is that a particle size "threshold" may exist in turbine design. In this case, if an economically tolerable erosion rate could be established for a certain particle size, say 40 microns, then the turbine may have a high degree of tolerance for larger size particles.

The work reported in Reference 3.7 also included investigation of the effect of chemical composition of particles from coal combustion on erosivity. Based on this bench-scale research, the percents by weight of aluminum, silicon and iron compounds were determined to be the major components governing erosion. A rationale is presented that the particles from the pressurized fluidized bed combustion (PFB) of coal using dolomite for $\mathrm{SO}_{x}$ control should be much less erosive then particles from conventional coal combusition. The rationale ard supporting data would tend to explain the low erosion rates reported in the turbine cascade tests from the Exxon PFB Mini-Plant [Refarence 3.9]. The Exxon results indicated a blade erosion life of 70,000 hours when compared to other turbine erosion experience in Table 5.1 of the first topical report of this series [Reference 3.10]. 
If further research validates that erosivity correlates with particie chemical composition, this could be particularly significant to the develupment of direct coal-fired turbines. If the isse of calcium absorbents - either injected in the turbine combustor or mixed with the fuel - proves successfut for $\mathrm{SO}_{x}$ control, then turbine erosion rates could be much less than that expectêd from coal-water slurry combustion results to dat?.

\subsection{Potential Technoloay Cptions}

In summary, there appears to be a significant technology base for improving erosion lives of critical components in commercial turbine designs. This technology base, though presentiy largely empirical in nature, could be used to extend turbine application limits where the loadings of 10 micron and smaller particles exceed that based on operating experience.

The trade off for such design modifications center on efficiency debits introduced by increasing biade thicknesses to allow for material loss due to erosion. The use of more erosion resistant materials or coatings could prove economical provided the 1 ife cycle cost of such materials is favorable in terms of reducing operating fuel costs (eficiency loss).

From an overall design standpoint, gas turbine conditions which would favor the use of a one or two stage turt ne using simple blade shapes could represent an optimum configuration for osive gas streams. Such a low pressure ratio configuration is discussed in section 4.3 .

Finally, ongoing turbine erosion research could be utilized in formulating a directed research program focusing on extending the results of the direct coal-fired turbine, proof-of-concept test program now in progress to a new generation of erosion tolerant turbine designs. Specific elements of such a program should include basic research on the erosivity of the products of combustion in the gas stream entering the turbine. Also, applied research should be carried out in developing improved design criteria for turbines operating in particle laden streams. 


\subsection{OPTIONS FOR IMPROVING SIMPLE CYCLE THERMODYNAMIC PERFORMANCE}

Turbine inlet temperature, pressure ratio and component efficiency govern the heat rate of open-cycle gas turbine systems. Reduction of turbine inlet temperature to mitigate the deposition, corrosion and erosion propensities of the coal-derived hot gases entering the power turbine imposes a debit on both efficiency and power output for a given turbine desigl.

Reductions of turbine inlet temnerature on the order of $400 \mathrm{~F}^{\circ}$ for present commercial gas turbine designs may lead to !neconomic direct ccal-fired turbine installations in terms of operating capital and fuel costs. An array of practical and hypothetical options exist to improve cycle efficiencies (reduce fuel cost) by introducing heat transfer equipment (at increased capital costs). Such options increase cycle power output and/or reduce fuel innsumption. These options are examined in this section from the viewpoints of operating experience with various cycle configurations, configurations which may be adaptable to fresent commercial designs, and nuvel cycle designs which would require major gas turbine redesian and development efforts.

\subsection{Experience with Alternative Gas Turbine Cycle Designs}

Many gas turbine installations of the early 1960 's utilized cycles with intercooling, reheat and recuperation to overcome metallurgical and turbomachinery component efficiency limitations of that era. These installations achieved component efficiencies of $59+\%$ and achievec cycle efficiencies of up to 34 percent, equal to today's simpie cycle machines with firing temperatures of $2000^{\circ} \mathrm{Ft}$.

This technolugy is documented in a recent Electric Power Research Institute (EPRI) report [Reference 4.1]. Experience with the many variations of the Brayton (constant pressure) cycle upon which commercial gas turbine designs are based is surveyed in the report. The variations include: "... the simple open cycle, the combined cycle, the intercooled cycle, the closed cycle, the semi-closed cycle, the reheat cycle, the compound cycle and various combinations of the aforemeritioned." Each cycle and/or combination of cycles is fully described in Section 3.0 of the EPRI report in terms of its configuration and thermodynamic temperature-entropy diagram. Accordingly, this information will not be repeated here and the reader is referred to Reference 4.1 for nomenclature regarding each cycle configuration.

The general conclusion from the EPRI report is that most of the cycles surveyed would be successful using today's technology. For example, use of the intercooled, reheat, regenerative gas turblie cycle in conjunction with the simple-cycle efficiency of 30 percent achievable today could raise gas turbine cycle efficiencies to a range of 50 to 55 percent.

Table 4.1 presents a summary of the open-cycle experience delineated in the EPRI report. A schematic of a compound cycle using intercooling, recuperation and reheat (essentially every type of cycle variation) is shown along with information relating to the design and operating information of a unit which 


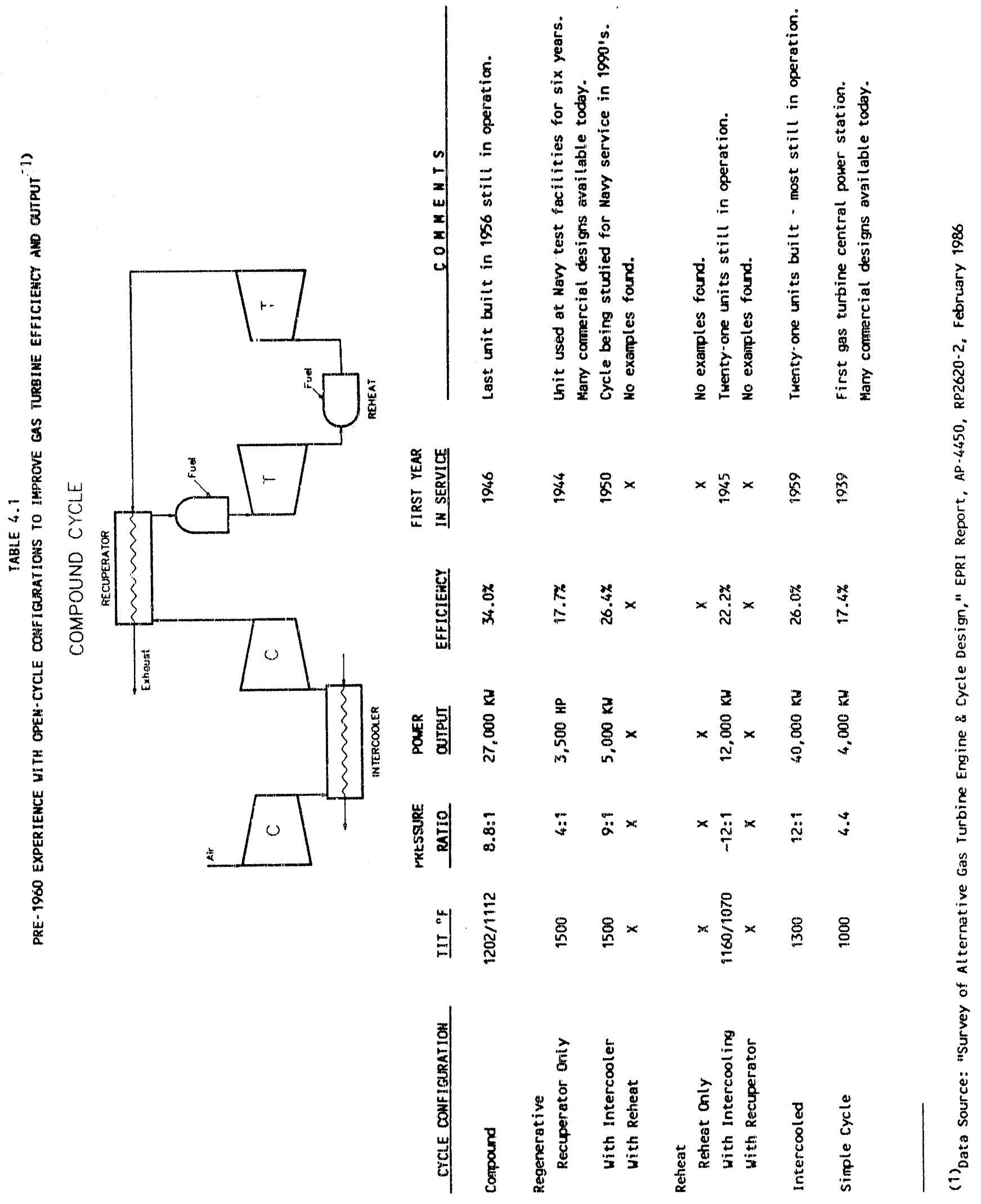


used a compound cycle. Similar information is also presented for variations in the compound cycle; i.e., without reheat, recuperation and/or intercooling, etc.

For the purposes of this study, the data in Table 4.1 indicate that the following cycle variations from the compound cycle have been successful commercial designs:

\section{CYCLE CONFIGURATION}

Simple.cycle

Regenerated cycle

Reheat cycle with Intercooling

Regenerative Cycle with Intercooling

Intercooled Cycle

\section{FIRST YEAR}

1939

1944

1945

1950

1959

\section{EFFICIENCY \% \%}

17.4

17.7

22.2

26.4

26.0

From the above tabulation, the addition of intercooling to either a simple or regenerative cycle commercial design would appear to be a practical machine modification to increase gas turbine efficiency for a given turbine inlet temperature and pressure ratio. Also, it would appear from Table 4.1, that a cycle using only reheat represents a non-commercial or novel cycle which may merit development for direct coal-fired turbine applications. These two cycle options may offset performance debits due to reduction of turbine inlet temperature. They are evaluated in Sections 4.2 and 4.3. The use of steam or organic bottoming cycles (combined cycle) is not considered; this technology exists today as a commercially-established performance option.

\subsection{Potential Options with Commercial Machines}

In general, modifying an existing simple cycle gas turbine to include a recuperator increases efficiency. The addition of intercooling further improves efficiency with a simultaneous increase in power output. The practicality of achieving these performance advantages is currently under investigation in a number of applied research programs.

From a thermodynamic viewpoint, the addition of a recuperator to an existing simple-cycle gas turbine utilizes the turbine exhaust heat to increase the temperature of the compressor discharge air entering the combustor. This reduces the amount of fuel needed to heat the gas to the temperature required at the turbine inlet. Thus there is an efficiency gain for the cycle. The efficiency gain is limited only by compressor discharge temperature considerations. For example at high compression ratios without intercooling, the compressor discharge temperature would approach the turbine exhaust temperature and no gain in efficiency would be achieved. (A compression ratio of 18:1 would equal a turbine exhaust temperature of $900^{\circ} \mathrm{F}$ ).

The addition of an intercooler, to cool the air at an intermediate point of the compression cycle, reduces the amount of compression work required. This power saving is available as additional power at the turbine output shaft. There is also an increase in efficiency and/or decrease in recuperator capital costs because the lower compressor discharge temperature favors increased heat transfer in the recuperator. 
Table 4.2 illustrates the foregoing commentary for a given turbine design with a turbine inlet temperature of $1800^{\circ} \mathrm{F}$ and a compression ratio of $10: 1$. The effect on efficiency and output by reducing the turbine inlet temperature to $1400^{\circ} \mathrm{F}$ is shown along with the benefits of adding regeneration and intercooling at the $1400^{\circ} \mathrm{F}$ temperature. It can be seen that the machine performance at $1800^{\circ} \mathrm{F}$ could be approached by the addition of carefuliy designed recuperation and intercooling modifications which would minimize cycle pressure drop losses.

The advantages of adding recuperation and intercooling to upgrade the performance of existing commercial gas turbine designs are being pursued in a number of applied research studies currently underway by various industrial and university orgarizations. These studies center on the use of specific commercial turbine designs to evaluate trade-offs in aerodyramic design (blade modifications to reduce efficiency losses) and turbine inlet temperature (blade cooling morifications) versus inefficiencies (increased cycle pressure and flow losses) introduced by the addition of recuperators and intercoolers to existing hardware. Specific studies known to be underway at this time involve the following types of engines:

\begin{tabular}{|c|c|c|c|}
\hline MANUFACTURER & MODEL NO. & POWER RATING & PRESSUCE RATIO \\
\hline $\begin{array}{l}\text { Garrett } \\
\text { Ingersoll-Rand } \\
\text { Pratt \& Whitney } \\
\text { Rolis-Royce }\end{array}$ & $\begin{array}{l}\text { DC } 990 \\
\text { GT22B } \\
\text { JT15-D } \\
\text { SMIA Spey }\end{array}$ & $\begin{aligned} 5800 \mathrm{HP} \\
4250 \mathrm{HP} \\
1400 \mathrm{HP} \\
12.75 \mathrm{MW}\end{aligned}$ & $\begin{array}{r}12: 1 \\
9.7: 1 \\
6.9: 1 \\
19: 1\end{array}$ \\
\hline
\end{tabular}

The payout for such applied research is good as the studies are focused on optimizing the development costs of commercially proven gas turbines. For example, the Rolls-Royce study for the U.S. Navy (see Table 4.1 comment) is being conducted by the Allison Gas Turbine Division of General Motors with the expectations that power output can be increased by $70 \%$ with an increase in efficiency of $30 \%$ [Reference 4.2]. The other studies using the machines in the above tabulaticil have similar objectives. Specific tetails of these studies are not available due to the proprietary nature of the work.

Such studies could prove attractive as a parallel research path for direct coal-fired turbine development should the results of proof-of-concept testing dictate a lower turbine firing temperature is required to avoid turbine fouling, erosion, or corrosion problems. The berlefits of this low-risk, low-cost research could greatly enhance direct coal-fired turbine development and obviously merit consideration as a research option to the full development of novel cycle configurations.

\subsection{Novel Cycle Designs}

The gas turbine cycle experience presented in Section 4.1 considered eleven combinations of various open-cycle thermodynamic configurations for the basic Brayton Cycle. Obviously other permutations exist but these would represent refinements of the basic configurations considered. of these cycle variations, only the reheat cycle has not been exploited in turbine designs. 


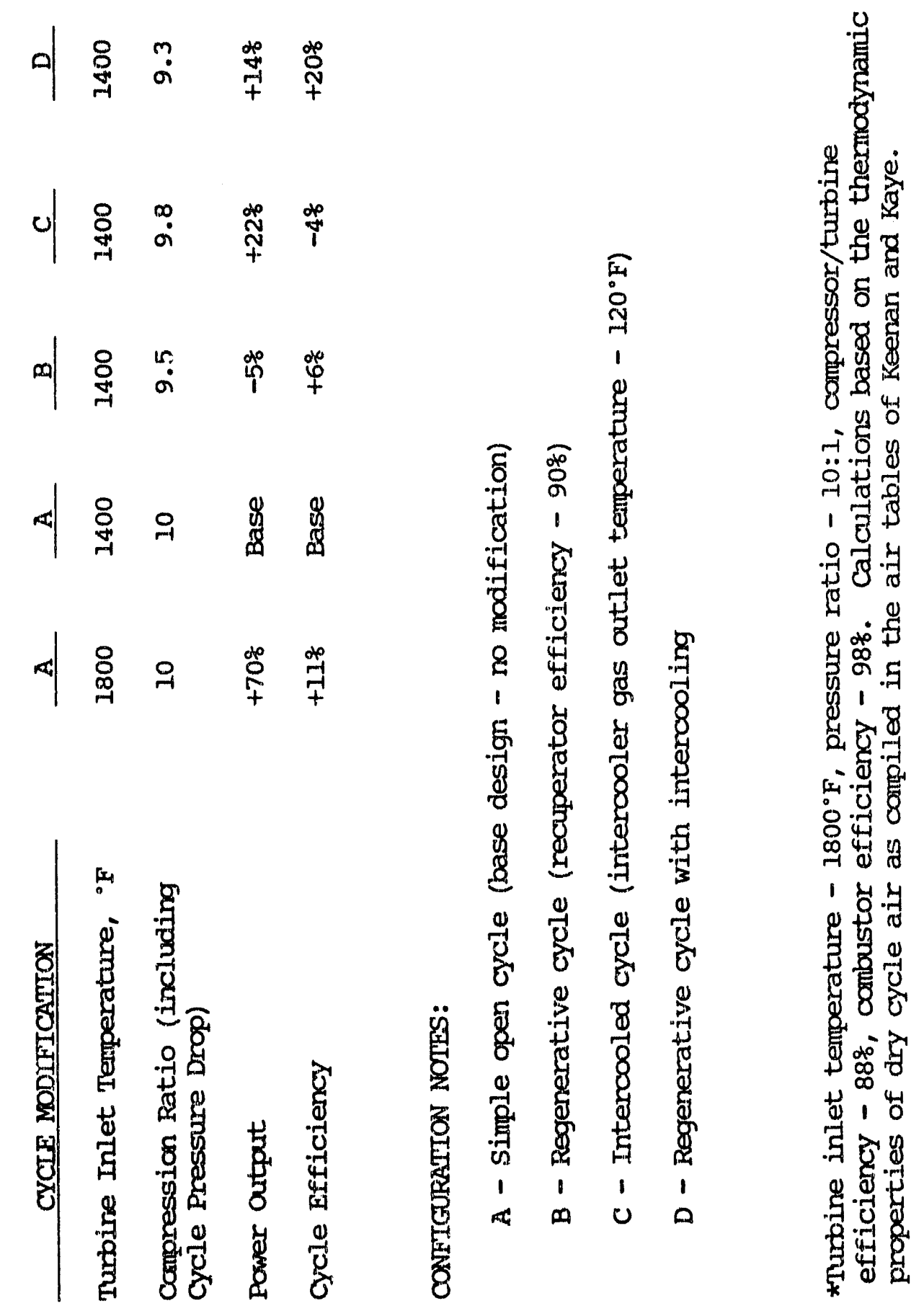


In addition, the analysis presented in Section 4.2 directionally indicates that reducing the pressure ratio of a regenerative cycle would increase the thermal effectiveness of the recuperator and thus reduce the amount of fuel required to heat the cycle air to the turbine inlet temperature. Such a low pressure ratio, regenerative cycle could offer efficiency advantages.* These two cycle configurations may offer performance advantages for direct coa?-fired turbine development compared to cycle modifications to commercially availabla simple cycle gas turbine designs.

The optimum efficiency and power output of a reheat cycle is highly dependent on pressure ratio [Reference 4.3]. A 124 MW reheat cycle gas turbine installation has recently been reported in the 1 iterature [Reference 4.4] as capable of achieving efficiencies approaching $40 \%$ based on a turbine inlet temperature of about $2300^{\circ} \mathrm{F}$ and a cycle pressure ratio of 55:1.

Additionally, a U.S. Patent [Reference 4.5] has been issued covering the use of burning supplemental fuel within the turbine rather than in an external reheat

combustor. Literature sources relating to this patent [References 4.6 and 4.7 ] indicate that cycle efficiencies on the order of 55 percent could be achieved with similar turbine inlet temperatures of $2300^{\circ} \mathrm{F}$ and pressure ratios on the order of $60: 1$.

The use of a compression ratio of about 55:1 requires the use of intercooling for economical compression design. Therefore the above cycles incorporate intercooling in addition to reheat of the cycle gas between turbine stages. Furthermore, such compression ratios would limit the use of this technology to turbomachinery power outputs greater than 10,000 horsepower. This is due to the increased penalty of boundary layer losses in designing axial and centrifugal compressors for discharge flows of less than 350 acfm at reasonable efficiencies (60 percent). Obviously, lowering the compression ratio to about $35: 1$ or using positive displacement compressors would extend this technology to matching approximately 5000 horsepower.

Table 4.3 shows a performance comparison of the above cycles at various pressure ratios for a turbine inlet temperature of $1400^{\circ} \mathrm{F}$. A conventional reheat cycle as indicated by cycle "A" in the table is shown to offer only marginal gains in efficiency over that of a simple cycle gas turbine. However significant power output advantages potentially could be obtained by using reheat in combination with pressure ratios ranging from 10:1 to 30:1. This could be attractive if the capital costs per unit power output are lower than that for a simple cycie gas turbine.

The reheat cycle indicated as cycle "B" in Table 4.3 involves burning some fuel directly in the power turbine rather than in an external reheat combustor to heat the expansion gas. Thermodynamically, the gas is expanded isothermally rather than isentropically as shown in the Temperature-Entropy

*A further explanation of the efficiency advantages of low-pressure ratio, regenerative cycle designs may be found in: The Design of High-Efficiency Turbomachinery and Gas Turbines, David Gordon Wilson, MIT Press, 1984, Chapters 3.3 through 3.6 . 


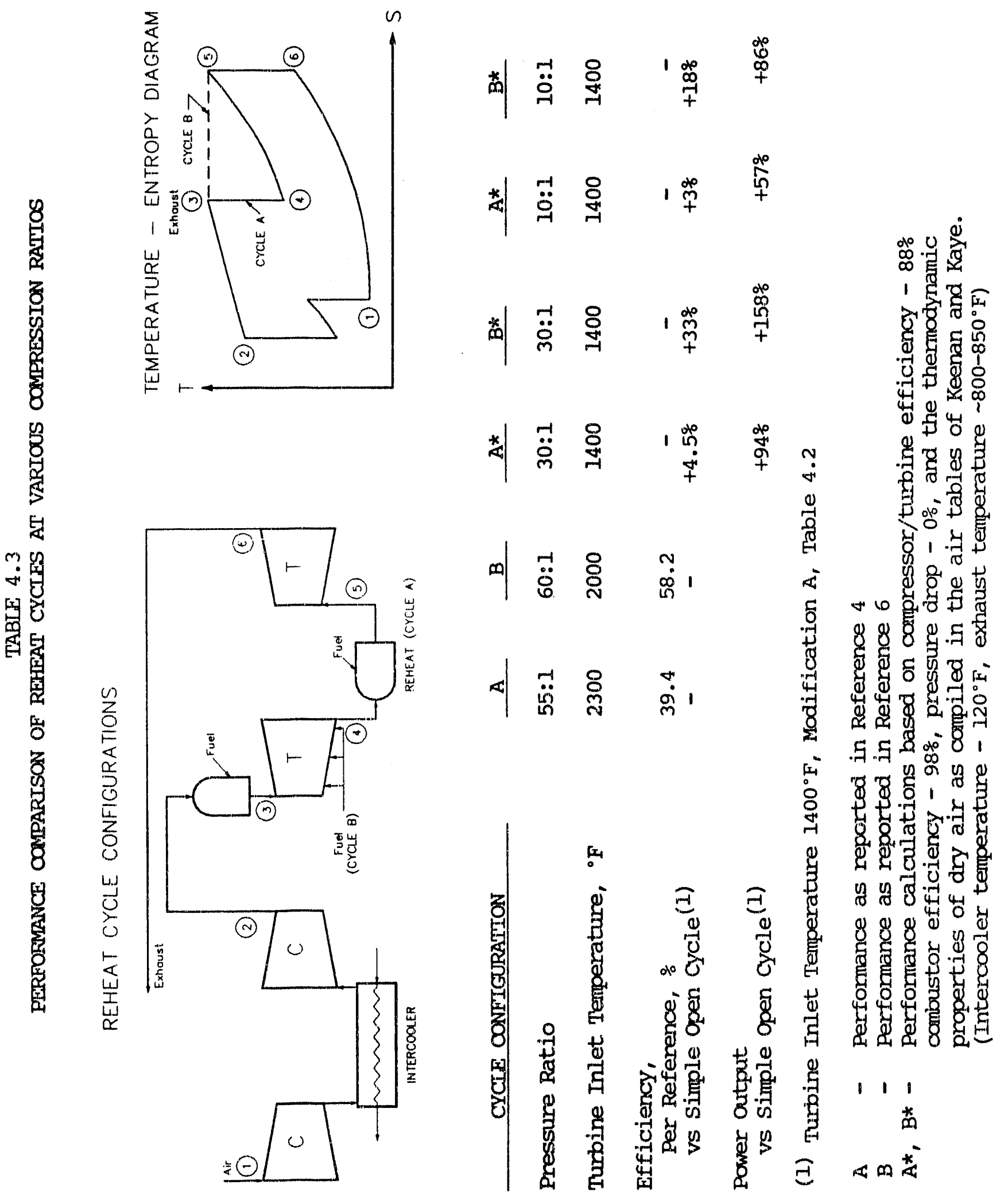


diagram of Table 4.3. The potential advantages of this configuration are significant in terms of both increased efficiency and power output over that of a conventional reheat cycle. The key development of this technology centers on the use of a catalytic combustor inside the turbine to obtain the required combustion rates for isothermal expansion. To date, the hardware for accomplishing this has not been demonstrated. In addition, only gaseous fuels or methanol are being considered.

The inain disadvantage of a high compression ratio gas turbine for direct coal-fired service is the design problems associated with handling an erosive gas stream in a turbine with a correspondingly higher number of stages than gas turbines with conventional cycle pressure ratios on the order of $10: 1$. This froblem would be further exacerbated with the use of a combustion promotion catalyst inside the turbine.

On the other end of the pressure ratio scale is the optimization of the regenerative gas turbine cycle. Pressure ratios on the order of 4:1 appear to optimize cycle efficiency as shown in Tabie 4.4. It should also be noted that a potential design trade-off exists for either optimizing power output (1ower capital costs) or efficiency (lower fuel costs).

The same trade-offs exist for the various machine modification performance options listed in Table 4.2. Existing commercia? turbine designs have favored maximizing power output to reduce capital costs. However, the economic value of these operating cost parameters has not been established for direct coal-fired turbine applications.

A comparison of the base power olltput and efficiency points shown in Table 4.4 versus those of a simple-cycle turbine operating at $1400^{\circ} \mathrm{F}$ and a pressure ratio of $10: 1$ from Table 4.2 (Modification $A$ ) indicates the following:

\section{TABLE $4.4 \quad$ TABLE 4.2}

Power Out $\quad+5 \% \quad$ Base

Erficiency $\quad+39 \% \quad$ Base

Thus for a turbine inlet temperature of $1400^{\circ} \mathrm{F}$, a low-pressure ratio, regenerative turbine could offer a 39 percent efficiency advantage over a simple-cycle turbine operating at a compression ratio of $10: 1$. This conclusion is valid only to the extent that the relative performance merits of derating existing commercial turbine cycle designs are compared to those for developing an alternative cycle design. As highlighted in the previous paragraphs, existing cycle designs are optimized based on capital cost rather than fuel cost considerations.

An additional advantage favering low-pressure ratio, regenerative turbine cycles is that the power turbine could be a one or two stage design rather than the three or more stages in existing commercial or alternative cycle designs. Reducing the number of power turbine stages directionally reduces capital costs. Additionally, the use of a turbine with less than three stages could significantly reduce development costs. This is because proven turbine designs exist for handling high-temperature, erosive gas streams at pressure ratios up to $4: 1$. 
TABLE 4.4

EFFECT OF CYCLE PRESSURE RATIO ON REGENERATIVE GAS TURBINE DESIGN*

AT A TURBINE INLET TEMPERATURE OF $1400^{\circ} \mathrm{F}$

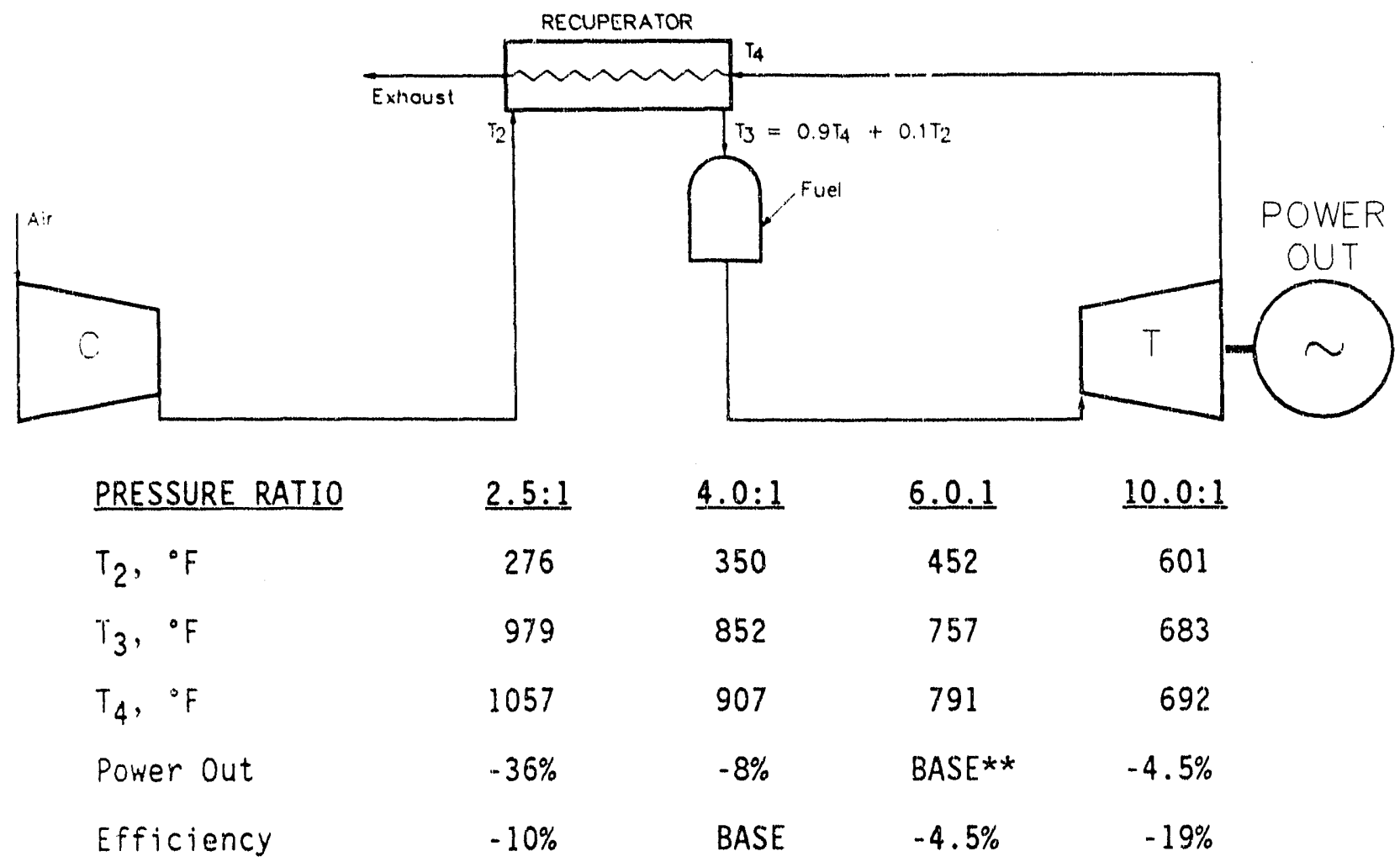

* Turbine inlet temperature - $1400^{\circ} \mathrm{F}$, compressor/turbine efficiency - $88 \%$, combustor efficiency - $98 \%$, recuperator efficiency - $90 \%$, cycle pressure drop - 0\%. Calculations based on the thermodynamic properties of dry cycle air as compiled in the air tables of Keenan and Kaye.

$* \star$ Representative of early commercial $1400^{\circ} \mathrm{F}$ gas turbine designs.

For example, Table 5.1 of the first topical report [Reference 1.1] used commercial "cat plant"* experience to compare the erosive effects of various gas streams on turbine life. This experience encompasses the use of one or two stage power recovery turbine designs operating in a $1400^{\circ} \mathrm{F}$ gas stream 1 aden with catalyst particles (mostiy $\mathrm{SiO}_{2}$ and/or $\mathrm{Al}_{2} \mathrm{O}_{3}$ ) at loadings up to 100 ppm ( $95 \%$ less than 10 microns) [References 4.8 and 4.9 ]. Such turbines are commercially available in sizes up to 50,000 horsepower and have a demonstrated operating life exceeding the one year desigl! life objective of the present DOE program.

*Refers to fluidized catalytic cracking process units used in petroleum refineries. 
If the experience and technology of commercial "cat plant" expanders could be utilized in the design of a low-pressure ratio, regenerative gas turbine, then the development and capital costs for such a turbine could be significantly reduced. However, the research success of this development would be highly dependent on a recuperator that is efficient and has a high tolerance for handiing particle laden streams.

\subsection{Summary}

In summary, several cycle options exist for improving gas turbine efficiency and power output should direct coal-fired turbine development dictate adjustments in turbine inlet temperatures to mitigate turbine fouling. These options are ranked in the following descending order of preference based on the author's views regarding practicality, probability of research success, and development costs required to achieve significant performance gains:

- Modifying Commercial Gas Turbine Designs

- Adding intercooler

- Adding recuperator

- Adding recuperator + intercooler

- Adding reheat + intercooler

- Developing Low Pressure Ratio Regenerative Turbine - Using "cat plant" expander technology

- Using new turbine design

- Developing Reheat Cycle Turbine

- Using high pressure design with conventional reheat combustor

- Using conventional pressure ratio designs (10:1) with insitu turbine catalytic combustion system

The above ranking is largely subjective in nature. Each of the options merit consideration for further feasibility or engineering studies of an applied research nature similar to that presently being carried out for specific gas turbine designs as highlighted in Section 4.2 . To select two or three of the most promising options requires further evaluation in terms of economic screening of research incentives as well as an evaluation of the impact of parallel advances in metallurgy for each option. 


\subsection{A GAS TURBINE DESIGN PERSPECTIVE ON HIGH TEMPERATURE MATERIALS TECHNOLOGY}

The high temperature performance potential of non-metals (ceramics) has not been fully achieved in present and near-future gas turbines operating on conventional fuels. These engineered materials are the focus of ongoing research directed at uncooled engine designs capable of operating at efficiencies and specific power outputs approaching that of theoretical cycle considerations. For direct coal-fired turbine design, the erosion and corrosion resistance of such materials may be more important than achievement of turbine inlet temperatures above current metallic superalloy limitations.

To date, ceramics utilization in stressed turbine components has only been for turbines developing les's than 500 horsepower. Typically such turbines, either commercially available or under development, involve applications for automotive, military and/or emergency power use.

Silicon carbide materials operating at turbine inlet temperatures of $2500^{\circ} \mathrm{F}$ have been developed to satisfy the intermittent service 1 ife requirements of less than 3000 hours for these applications [References 5.1 through 5.4].

Ceramics display brittle or non-ductile liehavior when stressed under tensile loadings. Design criteria for such non-ductile materials are fairly well established. These include the use of highly refined stress analysis methodology and statistical analys is of material properties [References 5.5 through 5.7]. The current limitations of stressed ceramic components to small sizes and relatively low performance (lifetime) are largely practical ones: Material processing techniques and inspection methods necessary for producing reliable and predictable larger-size components have yet to be perfected [References 5.8 and 5.9].

On the other end of the scale, industrial and utility turbines approaching $100 \mathrm{MW}$ in size and with turbine inlet temperatures of $2300^{\circ} \mathrm{F}$ are commercialiy available. These designs have been achieved through the use of air cooling and metallic coating of the turbine blading. Both diffusion and overlay coatings are used to increase the oxidation/corrosion resistance of the nickel- and cobalt-based turbine blade alloys that are used at temperatures above $1400^{\circ} \mathrm{F}$ [Reference 5.10 ]. Cobalt-chromium-aluminum overlay coatings ip to 0.008 inches thick represent the current state of the art for industi ial turbine designs [References 5.11 and 5.12].

Ceramic overlay coatings of zirconium oxide are currently being developed for aircraft engines [References 5.10 and 5.13]. Coatings up to 0.020 inches thick are applied over a metallic overlay precoating (usually NiCrAlY type). The precoating assists in bonding. The overall coating system acts as a thermal barrier that lowers metal temperatures. The system also improves oxidation/corrosion resistance. The promise of such coatings is that both efficiency and specific power can be increased through increased firing temperatures and reductions in cooling air. 
Reference 5.14 presents an assessment of these potential benefits for commercial $50 \mathrm{MW}$ turbine designs. It was found that the use of a 0.030 inch thick coating system could permit an increase in turbine inlet temperature of about $100 \mathrm{~F}^{\circ}$ while reducing cooling air by about 25 percent. However, these advantages were somewhat offset by increased aerodynamic losses in the turbine blading introduced by the increased blade thickness (See Section 3.1).

The performance of ceramic coating systems operating in an erosive gas stream has not been established. A 1 imited investigation involving comparison testing of various coatings found sprayed $\mathrm{ZrO}_{2} / \mathrm{CoCrAlY}$ to have satisfactory erosion resistance for aircraft engine turbine sealing systems operating at $2400^{\circ} \mathrm{F}$ [Reference 5.15]. As expected, maximum erosion rates occurred at an impingement angle of 90 degrees versus an impingement angle of 45 degrees for the more ductile metaliic coatings. This could be an important point to consider in the use of nonductile coatings to achieve more erosion-tolerant turbine blading.

Directionally, the oxides of zirconia, alumina and silica should offer maximum erosion resistance. The development of these coatings, as well as basic design information relative to the erosion of commercial coating systems, may represent key research needs for the direct coal-fired turbine research and development program [Reference 5.16].

Past experience indicates that typical research lead times for deveioping coating technologies are on the order of four to eight years [Reference 5.17]. Therefore the research impact on the direct coal-fired turbine research and development program may be outside the time frame of the current DOE proof-of-concept prograin.

The development of a high temperature recuperator capable of resisting the potentially highly corrosive and erosive nature of coal combustion streams could also be extremely important. The gas turbine cycle analysis presented in Section 4.3 highlights the performance advantages of a regenerative cycle either in the modification of existing turbines or in the development of a low-pressure ratio regenerative gas turbine.

A significant body of design, fabrication and operating experience exists for ceramic heat exchangers [Reference 5.18]. This experience could be brought to bear in developing a successful design for use in direct coal-fired turbine regenerators. Ceramic heat exchangers would have lower stress levels and more favorable geometry than stressed turbine components. Thus the complete range of ceramics - oxides, nitrides, carbides, etc. - may be considered for gas turbine regenerators. These materials have found extensive application in coal fired power plants [Reference 5.19].

An example of the type of ceramic recuperator that could be adopted for coal-fired turbine use is one similar to that which has been studied by EPRI for closed-cycle gas turbine applications [Reference 5.18]. In this two-pass cross-counterflow design, gases from the combustion of pulverized coal are used to heat the turbine cycle air. Modular construction using one inch diameter silicon carbide tubes was evaiuated. The resulting configuration had a surface compactness (ratio of heat transfer surface to volume) of about one-tenth that of current plate-fin recuperator designs. 
Applied research studies could be used to extend and optimize such a design with careful attention to the erosive and fouling characteristics of the turbine exhaust gas. The use of plate-fin construction may be precluded based on current investigations into gas turbine recuperator fouling with conventional fuels [Reference 5,20 ].

In summary, the thrust of past and current materials research for gas turbine applications has focused on increasing turbine inlet temperatures. Experience with advanced refractory metal alloys in marine environments and/or fuels with corrosive contaminants has led to the development of protective overlay coatings. These coatings primarily serve to overcome the poor oxidation resistance of "superalloys" at temperatures above $1400^{\circ} \mathrm{F}$.

The applicability of this technology base for direct coal-fired turbine design remains to be established. In particular, the erosion and corrosion resistance of current material systems need to be evaluated. The evaluation should be carried out for the temperature range found necessary to control turbine fouling. (See discussion in the first topical report of this series, Reference 1).

Zirconiun oxide coating systems for turbine components have been developed recently. The performance of this class of ceramic coatings in direct coal-fired turbine environments should be a long-term research priority. In addition, the research should factor in relevant experience with coal combustion systems. Also, present ceramic technology may offer recuperator aosigns which could enhance coal-fired, regenerative cycle gas turbine performance. The capture of this technology base could be pursued in an applied research study directed at the current DOE proof-of-concept program. 


\subsection{POTENTIAL RESEARCH OPTIONS TO BE EVALUATED}

Various technology options for addressing potential direct coal-fired turbine development needs in the areas of erosion, thermodynamic and materials performance have been identified in the previous report sections. The underlying assumption in this assessment is that turbine operating cunditions can be adjusted to limit turbine run-length power losses due to fouling to about three percent as discussed in the previous topical report [Reference 6.1]. Additionally, corrosion concerns have not been specifically addressed as the corrosive nature of the gas stream entering the turbine has not been sufficientiy characterized and is the focus of ongoing programs. However, the design role that ceramic technology could play toward increasing turbine erosion/corrosion tolerance has been highliginted.

To provide an independent assessment of the large body of information which exists in gas turbine technology, telephone contacts were made with individuals currently involved in gas turbine design and research outside the DOE Program. The individuals contacted, representing a cross-section of industry, academic and technical society interests, are listed on the Acknowledgements page at the beginning of this report.

The consensus opinion which evolved from these telephone contacts may be summarized by the fol? owing four points:

- Turbines can be designed to accept particles larger than ten microns in diameter with loadings up to $600 \mathrm{ppm}$. However, there is always a loss in efficiency when designs are based on erosion considerations.

- Numerous, practical cycle modifications can be made to existing turbine designs to improve efficiency and/or power output. These improvements could be used as trade-offs to offset performance debits due to reductions in turbine inlet temperature and/or the use of more erosion-tolerant turbine blading.

- Turbine inlet temperatures will most likely need to be adjusted (downward) to avoid turbine fouling problems. Temperatures as low as $1400^{\circ} \mathrm{F}$ may be necessary based on other experience with ash laden streams. No novel design approaches that would alleviate the turbine fouling in baseload service are immediately apparent.

- Designs for cycle configurations using proven commercial components could be established in about one year through the use of applied research studies.

The above consensus summary would appear to support the major technical thrust of this report. All of the individuals contacted underscored the value of applied research studies directed at analyzing specific turbines and designs. To summarize this recommendation, as well as to capture the many suggestions that were offered, a matrix of potential research options is shown in Table 6.1. 

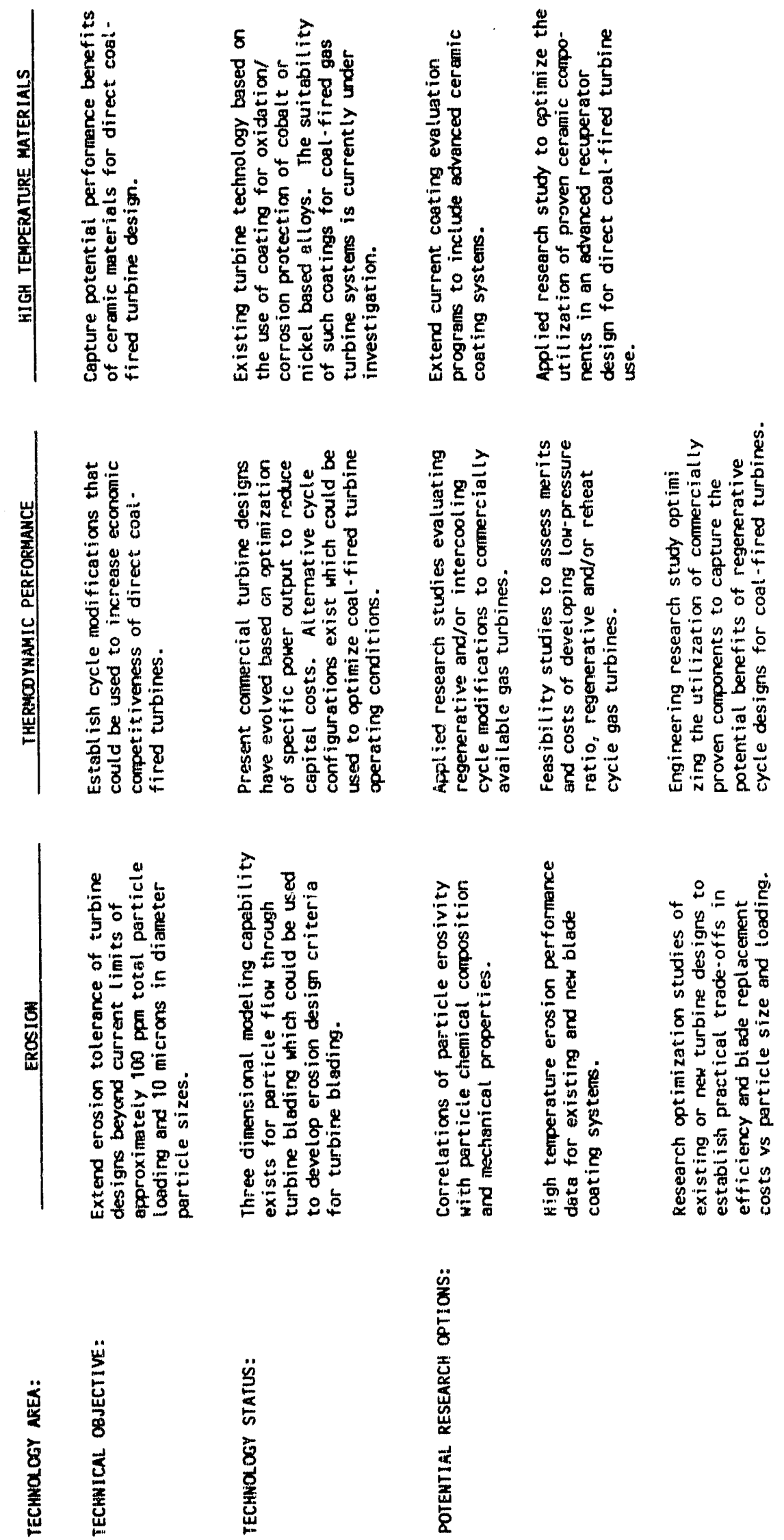
Table 6.1 is organized to highlight the type of research studies that could be carried out to accomplish a set of possible technical objectives based on the current technical status of the technology. It can be seen that there is a high degree of interdependance among the technology areas. For example, cycle configurations which favor the use of proven components may prove optimum negating the need for other areas of research. On the other hand, fundamental bench scale research in erosion testing of ceramic coatings may be required to develop new turbine blading designs.

The above ramifications and incentives for research will be the subject of the next and final topical report. 


\section{REFERENCE FOR CHAPTER 1}

INTRODUCTION

1.1. R. L. Thomas, "An Assessinent of Off-Design Particle Control Performance on Direct Coal-Fired Gas Turbines, "Draft Topical Report for Task 14 submitted to METC January 11, 1988 under Contract No. DE-AC21-85MC22012.

\section{REFERENCES FOR CHAPTER 3}

TECHNOLOGY OPTIONS FOR IMPROVING EROSION PERFORMANCE

3.1 M. J. Zucrow, Jet Propulsion and Gas Turbines, John Wiley and Sons, 1951 .

3.2 "Gas Turbine Systems Research and Development Program," Topical report for Period June 6, 1983 - October 19, 1984, DOE/MC/20324-1765, March 1985.

3.3 "1987 International Gas Turbine and Aeroengine Technology Report," International Gas Turbine Institute, Atlanta, Georgia.

3.4 A. Hamed et al, "Turbine Erosion Exposed to Particulate Flow, " ASME Paper 86-GT-258.

3.5 Muhsin Menguturk et al, "Multistage Turbine Erosion," ASME Paper 86-GT-238.

3.6 A. Hamed and S. Fowler, "Erosion Pattern of Twisted Blades by Particle Laden Flows," ASME Paper 83-GT-214.

3.7 R. Kotwal and W. Tabakoff, "A New Approach for Erosion Prediction Due to Fly Ash," ASME Journal of Engineering for Power, Aprit 1981, Vol. 103, p. 165 .

3.8 W. Tabakoff et al, "Study of Metals Erosion in High Temperature Coal Gas Streams," ASME Journal of Engineering for Power, January 1980, Vol. 102, p. 148.

3.9 M. S. Nutkis, "Pressurized Fluidized Bed Coal Combustion Exposure Testing of Gas Turbine and Heat Exchange Materials, "ASME Paper 79-GT-166.

3.10 Thomas, R. L., "An Assessment of Off-Design Particle Control Performance on Direct Coal-Fired Gas Turbine Systems, " Draft Topical Report under Contract No. DE-AC21-85MC22012 Task 14, January, 1988. 
4.1. "Survey of Alternative Gas Turbine Engine and Cycle Design, "EPRI Report AP-4450, (RP2620-2), February 1986.

4.2. "ICR Marine Propulsion System Makes Cruise Engine Obsolete, "Gas Turbine World, July-August 1988.

4.3 I. G. Rice, "The Combined Reheat Gas Turbine/Steam Turbine Cycle," ASME Journal of Engineering for Power, Vol 102, January 1980.

4.4. "Japan's 124 MW High-Temp Pilot Plant Ready for Test", Gas Turbine World, September-October 1983

4.5. "Gas Turbine Power System with Fuel Injection and Combustion Catalyst," U. S. Patent No. 4,197,700, April 15, 1980.

4.6. C. E. Jahnig, "30 Percent Fuel Saving by Adding Combustion Within Gas Turbine," ASME Paper 81-JPGC-GT-4.

4.7. C. E. Jahnig, "60\% Efficient Gas Turbine System for Base Load Use," ASME Paper 85-GT-145.

4.8 H. L. Franzel, "Maintenance of FCC Power Recovery systems, " Hydrocarbon Processing, January 1985.

4.9 David H. Linden, "Catalyst Deposits in FCCU Power Recovery Systems Can be Controlled," 0il \& Gas Journal, December 15, 1986.

REFERENCES FOR CHAPTER 5

A GAS TURBINE DESIGN PERSPECTIVE

ON HIGH TEMPERATURE MATERIALS DESIGN TECHNOLOGY

5.1 J. C. Napier, "Application of All-Ceramic Nozzle to Radial Flow Turbine," ASME Journal of Engineering for Power, Vol 102, April 1980.

5.2 Lance E. Groseclose and Richard A. Johnson, "Status of the AGT100 Advanced Gas Turbine Program," ASME Paper 85-GT-205.

5.3 J. R. Kidwell and D. M. Kreiner, "AGT 101-Advanced Turbine Technology Update," ASME Paper 85-GT-177.

5.4 M. 0. Teneyck et al, "Hot Isotatic Pressing of Sintered Alpha Silicon Turbine Components, " ASME Journal of Engineering for Gas Turbines and Power, Vol 109, July 1987.

5.5 W. H. Dukes, "Brittle Materials: A Design Challenge, " Mechanical Engineering, November 1975. 
References for Chapter 5 - continued

5.6 G. Trantina and C. Grondah1, "Demonstration of Ceramic Design Methodology for a Ceramic Combustor Liner," ASME Journal of Engineering for Power, Vol 101, July 1979.

5.7 P. J. Coty et al, "A Design Review of Ceramic Components for Turbine Engines," ASME Journal of Engineering for Power, Vol 102, Apri1 1980.

5.8 M. Srinivasan and M. Earl, "Quality Assurance in Manufacturing High Performance Ceramics," ASME Journal of Engineering for Gas Turbines and Power, Vol 109, April 1987.

5.9 G. Y. Baaklini, "NDE Reliability and Process Control for Structural Mechanics," ASME Journal of Engineering for Gas Turbines and Power, Vol 109, Juity 1987.

5.10 A. A. A. Mom and H. J. Kolkman, "Corrosion and Corrosion Control in Gas Turbines Part II: The Turbine Section," ASME Paper 84-GT-256.

5.11 Donald E. Brandt, "Heavy-Duty Turbopower: The MS7001F," Mechanical Engineering, July 1987.

5.12 A. McMinn et al, "Field Evaluation of Gas Turbine Protective Coatings," ASME Journal of Engineering for Gas Turbines and Power, Vol 110, January 1988.

5.13 S. C. Singhal and R. J. Bratton, "Stability of a $\mathrm{ZrO}_{2}\left(\mathrm{Y}_{2} \mathrm{O}_{3}\right)$ Thermal Barrier Coating in Turbine Fuel with Contaminants," ASME Journal of Engineering for Power, Vol 102, October 1980.

5.14 John S. Clark et al, "Potential Benefits of a Ceramic Thermal Barrier Coating on Large Power Generation Turbines," NASA TM 73712, June 1977.

5.15 L. T. Shiembob et a1, "Development of Ceramic Seal System for Turbine Gas Path Sealing," ASME Journal of Engineering for Power, Vol 101, October 1979.

5.16 "Materials \& Components Newsletter," DOE/FE-0072/72, Number 72, February 1988.

5.17 "Advanced Materials and Coatings," General Electric Co. Publication GER-2182M, Copyright 1979.

5.18 C. F. McDonald, "The Role of the Ceramic Heat Exchanger in Energy and Resource Conservation," ASME Journal of Engineering for Power, Vol 102, Apri1 1980.

5.19 John Reason, "Ceramics Improve Performance, Extend Life of Today's Power Plants," Power, December 1986.

5.20 T. L. Bowen et al, "Experimental Investigation of Gas Turbine Recuperator Fouling," ASME Journal for Gas Turbines and Power, Vol 109, July 1987. 

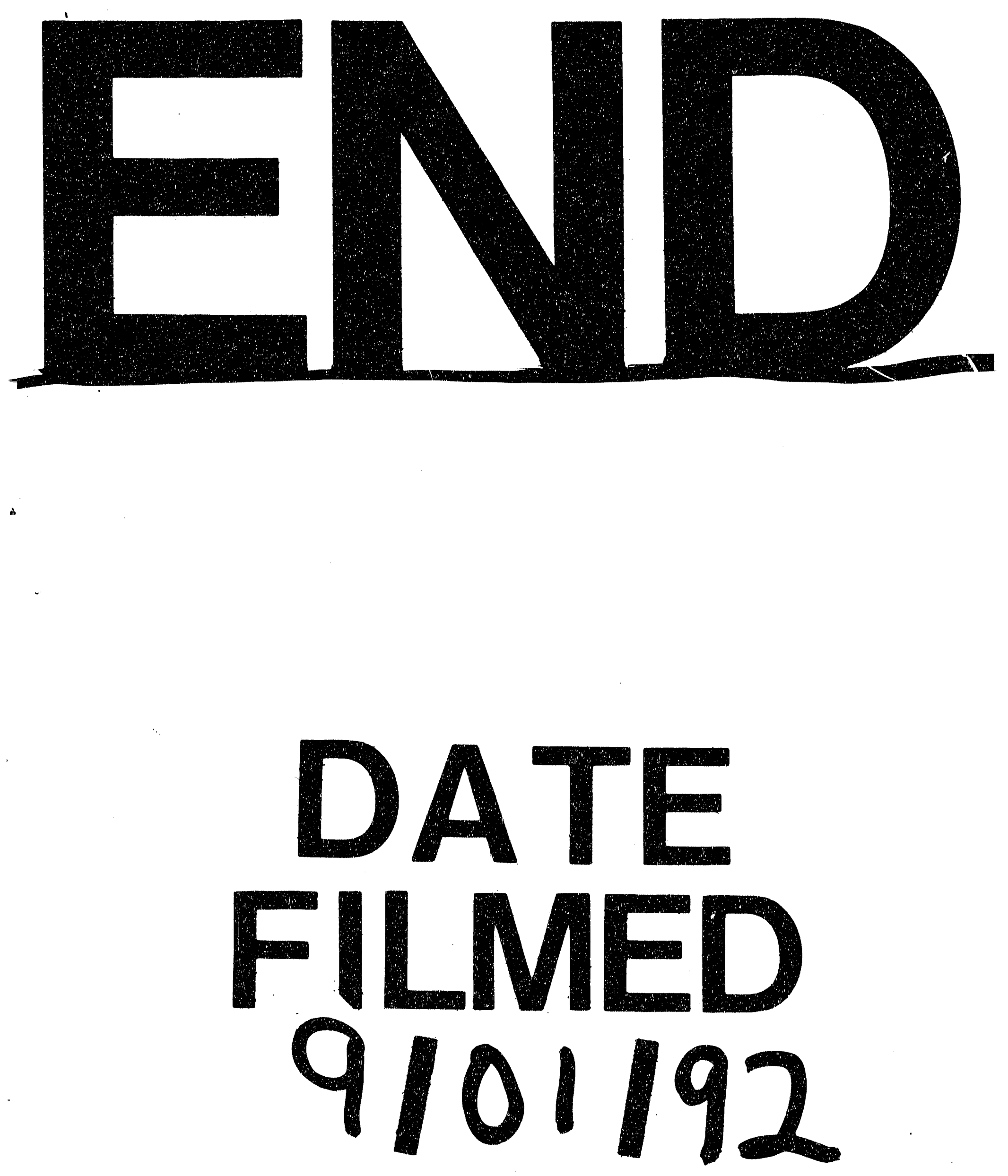
